\title{
Edytorskie problemy i wątpliwości związane z polskim wydaniem rosyjskojęzycznych listów Marii Sieroszewskiej do ojca (1925-1933)
}

\section{Grażyna Legutko}

(Uniwersytet Jana Kochanowskiego w Kielcach)

Niezwykle obfita korespondencja Wacława Sieroszewskiego - znajdująca się w większości w Zakładzie Rękopisów Biblioteki Narodowej w Warszawie - cieszyła się dotychczas umiarkowanym zainteresowaniem polskich edytorów. Sporo uwagi poświęciła jej Barbara Kocówna, która w I964 roku wydała osiemnaście listów pisarza z Syberii, wysyłanych w latach I888-ı89 do siostry Pauliny Sieroszewskiej, a w 1999 roku - cztery listy Sieroszewskiego do Grigorija Nikołajewicza Potanina i jego żony Aleksandry Wiktorownej z lat $1892^{-1}-183^{\mathrm{I}}$. W nie mniejszym stopniu zasłużyła się dla upowszechnienia epistolografii autora Na kresach lasów przedwcześnie zmarła badaczka jego twórczości Ida Sadowska, która w 2006 roku ogłosiła jedenaście listów Sieroszewskiego do Stefana Żeromskiego i Oktawii Żeromskiej, pochodzących $z$ lat $1897-1902^{2}$, a także przygotowała do druku kilkanaście listów pisarza do różnych osób, w tym: trzy do Józefa Piłsudskiego (z lat 1915-1922), trzy do Henryka Gierszyńskiego (z lat I9II-I9I2), pięć do Michała Sokolnickiego (z I9I5 roku), jeden do Bolesława Wysłoucha (z I9I2 roku), a ponadto kilka listów pisanych do Sieroszewskiego: jeden przez Mariana Stępowskiego (z r9I5 roku) i dwa przez

1 Zob. W. Sieroszewski, Listy z Syberii, oprac. B. Kocówna, w: Miscellanea z pogranicza XIX i XX wieku, red. S. Pigoń, „Archiwum Literackie”, t. 8, Wrocław-Warszawa-Kraków 1964, s. 383-424 i nadb. oraz Syberyjscy mistrzowie Sieroszewskiego. Listy do G.N. i A.W. Potaninów, oprac. B. Koc, „Blok-Notes Muzeum Literatury im. Adama Mickiewicza" 1999, nr 12/13, s. 329-360 (spośród czterech listów wysłanych do Potaninów jeden - adresowany do Aleksandry Potaniny - został napisany przez jedenastoletnią córkę Sieroszewskiego).

2 Zob. Listy Wactawa Sieroszewuskiego do Stefana Żeromskiego i Oktawii Żeromskiej z lat 1897-1902, w: Literatura $i \dot{z} y c i e$ artystyczne XIX i XX wieku. Prace ofiarowane Profesorowi Zdzistawowi Jerzemu Adamczykowi w roku Jubileuszu, red. B. Utkowska i K. Jaworski, Kielce 2006, s. 299-307. 
Bolesława Wieniawę-Długoszowskiego (z I9I9 roku) ${ }^{3}$. Ja z kolei w 2007 roku wydałam obszerny zespół (liczący dziewiętnaście listów) wzajemnej korespondencji Sieroszewskiego, Gustawa Daniłowskiego i Jadwigi Daniłowskiej, obejmujący lata I9OI-I927 $7^{4}$.

Pomysł przygotowania edycji mało znanych, pisanych po rosyjsku - w latach dwudziestych i trzydziestych XX wieku - listów mieszkającej w Moskwie Jakutki Marii Sieroszewskiej do swojego ojca, zrodził się w czasie pracy nad książką Wśód obcych i wśród swoich. Wactawa Sieroszewskiego portret wielokrotny (Kielce 2007), gromadzącą studia i szkice Idy Sadowskiej, które po śmierci autorki postanowiłam wydać w osobnym tomie, by ocalić od zapomnienia jej cenne refleksje krytycznoliterackie na temat twórczości Sieroszewskiego, rozproszone w rozmaitych czasopismach naukowych i pracach zbiorowych. W tej publikacji znalazł się między innymi intrygujący artykuł Egzotyczne rodziny polskich zestańców syberyjskich - przypadek Wactawa Sieroszerwskiego ${ }^{5}$, dotyczący często pomijanego albo marginalizowanego przez badaczy aspektu zesłańczych dziejów pisarza, mianowicie jego azjatyckiej rodziny - żony Ariny Czełba-Kysy (Anny Slepcowej) oraz urodzonej z tego związku córki, Marii, którą Sieroszewski uznał formalnie za swoje dziecko ${ }^{6}$. Arina była młodszą siostrą Iriny Slepcowej - żony Jana Zaborowskiego, uważanego wówczas za najważniejszą osobę w zesłańczej społeczności Wierchojańska ${ }^{7}$, dokąd dwudziestodwuletni Sieroszewski, skazany na wygnanie i dożywotnie

3 Zob. G. Legutko, I. Sadowska, Bojownicy polskiej sprawy. Wactaw Sieroszerwski i Gustaw Danitowski wobec myśli i czynu Józefa Pitsudskiego (Wybór materiatów z lat 1898-1943), Kielce 2007, s. 92-96 i 122-136 [książka wydana po śmierci Idy Sadowskiej].

4 Ibidem, s. 97-121. Przedr.: G. Legutko, W kregu mtodopolskiej epistolografii. Z korespondencji Zenona Przesmyckiego, Zygmunta Sarneckiego, Jerzego Zutawskiego Gustawa Danitowskiego, Wactawa Sieroszewskiego oraz Zofii Trzeszczkowskiej i Marii Sieroszewskiej, Kielce 2017, s. 153-181. Należy również pamiętać o ważnej pracy rosyjskiej badaczki Ludmiły Rowniakowej Wactaw Sieroszerwskij i jego russkije korespondenty (w: eadem, Stawianskije litieraturnyje swiazi, Leningrad 1968, s. 142-144), mieszczącej listy Sieroszewskiego do Władimira Korolenki i do G.N. i A.W. Potaninów (z 1895 i 1902 r.), a ponadto o drukowanych w rozmaitych miejscach pojedynczych listach pisarza do redakcji czasopism (m.in. „Głosu Prawdy”, „Gazety Warszawskiej”, „Przeglądu Literackiego”, „Gazety Polskiej”) i różnych osób (np. do L. Méyeta, P.P. Siemionowa Tian-Szanskiego, I. Daszyńskiego i J. Kleinera), a także o publikacji pojedynczych listów pisanych do Sieroszewskiego (m.in. przez S. Przybyszewskiego, S. Żeromskiego czy S. Downarowicza). Zob. Sieroszerwski Wactaw (1858-1945), „Nowy Korbut”, t. 15: Literatura pozytywizmu i Mtodej Polski (Hasta osobowe: M-Ś), oprac. zespół pod red. Z. Szweykowskiego i J. Maciejewskiego, Warszawa 1978, s. 542-544.

5 Zob. I. Sadowska, Wśród obcych i wśród swoich. Wactawa Sieroszerwskiego portret wielokrotny, red. G. Legutko, Kielce 2007, s. 149-161. Artykuł ten był pierwotnie zamieszczony na łamach „Prac Polonistycznych" 2006, Seria 61, t. 2, s. 177-188.

6 Prawne usankcjonowanie Marii jako swego dziecka i otrzymanie zgody władz carskich na noszenie przez córkę nazwiska ojca stało się możliwe dopiero w 1890 r., po dziesięciu latach przebywania Sieroszewskiego na zesłaniu, kiedy udało mu się uzyskać przypisanie do włościan gminy Tiuchtiur (położonej w pobliżu Jakucka) i zostać jej prawnym członkiem.

7 Zob. A. Sieroszewski, Słowo i czyn. Życie i twórczość Wactawa Sieroszerwskiego, w: Z kraju nad Leną. Związi polsko-jakuckie dawniej i dzis, red. A. Kuczyński, Wrocław 2001, s. 136-141. 
osiedlenie się w najodleglejszych miejscowościach północno-wschodniej Syberii, przybył w maju i88o roku. Jego związek z Ariną trwał krótko, zaledwie pięć lat (z czego dwa lata uciekinier musiał spędzić w odosobnieniu), żona przyszłego pisarza zmarła bowiem na przełomie I886 i I887 roku wskutek gruźlicy połączonej z zapaleniem płuc.

Rekonstrukcja tej niebywale ciekawej, w wielu miejscach kryjącej wciąż nierozwiązane zagadki, historii rodzinnej Sieroszewskiego możliwa jest, przynajmniej do pewnego stopnia, właśnie dzięki zachowanym listom jego pierworodnej córki. $\mathrm{Na}$ listy te powoływała się przed Sadowską Kocówna, a po niej - wnuk pisarza Andrzej Sieroszewski oraz Aleksandra Kijak, autorka książki Odkrywca innej Syberii i Dalekiego Wschodu. O prozie Wactawa Sieroszerwskiego (Kraków 2oro). Spośród polskich badaczy jednak nikt nie podjął się dotąd trudu ich publikacji. W ostatnim czasie rosyjskojęzyczne oryginały listów Marii Sieroszewskiej do ojca ogłosiła na łamach jakuckiego pisma „Jakutskij Archiw” Kunnej Takasajewa (Kunnej Takaahaj) ${ }^{8}$. Publikacja ta nie spełnia wszakże wymogów edytorskiej rzetelności, pozbawiona jest rzeczowych przypisów, zawierających objaśnienia treści listów (poruszanych w nich spraw, występujących osób, sytuacji politycznej itd.), a także wyczerpującego komentarza tekstologicznego. Pod listami nie zostały zamieszczone metryczki informujące o wyglądzie autografów, ich dokładnym formacie, stanie dochowania (np. ubytkach, zaplamieniach, czytelności tekstu).W krótkim trzystronicowym wstępie, poprzedzającym ogłoszone drukiem rękopisy Sieroszewskiej, jakucka badaczka wzmiankuje jedynie o dobrym stanie dokumentów, ich przybliżonym formacie i przyznaje szczerze, że korzystała $\mathrm{z}$ fotokopii, a w ręku miała oryginał tylko jednego listu, którego nie udało się jej odczytać z mikrofilmu (z powodu wyblakłego pisma listu napisanego ołówkiem). We wstępie Takasajewa podejmuje także próbę lapidarnej prezentacji zawiłej biografii azjatyckiej córki Sieroszewskiego ${ }^{9}$, podążając tropem wskazówek obecnych w jej listach do ojca oraz wykorzystując informacje dostępne w literaturze przedmiotu dotyczącej życia i twórczości autora Dwunastu lat w kraju Jakutów. Poza tym badaczka dotarła tylko do części zachowanej korespondencji, mianowicie do dwudziestu czterech listów Marii Sieroszewskiej do ojca, które znajdują się w Zakładzie Rękopisów Biblioteki Narodowej w Warszawie ${ }^{\mathrm{IO}}$.

8 K.R. Takasajewa, Pis'ma M.W. Sieroszerwskoj (1882-1964) otcu Wactawu Sieroszerwskomu, „Jakutskij Archiw" 2013, nr 1 (44), s. 80-101.

9 Odtworzeniem zagadkowej biografii i osobowości Marii Sieroszewskiej zajmowałam się w studium Meandry ojcowskiej mitości. Wokót listów jakuckiej córki Wactawa Sieroszerwskiego („Wrocławskie Studia Wschodnie” 2012, nr 16, s. 43-75) oraz w artykule Mitologizacja przesztości i problem z tożsamościa. Uwagi na marginesie listów Marii Sieroszerwskiej (w: Tożsamość - Czas - Pamięć, red. B. Morzyńska-Wrzosek, I. Szczukowski, Bydgoszcz 2017).

10 W zespole Listy do Wactawa Sieroszerwskiego od różnych osób (485 listów z lat 1902-1934), BN, rkps 5193, k. 72-109. 
Pochodzą one, o czym była mowa, z okresu dwudziestolecia międzywojennego a dokładnie obejmują około sześciu lat: pierwszy został napisany w kwietniu, najprawdopodobniej I928 roku (zawiera ważne wyznania piszącej związane z problemem jej tożsamości narodowej), ostatni - w sierpniu, zapewne I933 roku (znajdują się $\mathrm{w}$ nim refleksje na temat samotnego borykania się z trudną sytuacją życiową i wspomnienia odnoszące się do kaukaskiej przeszłości Marii).

Pozostałe znane mi listy Marii Sieroszewskiej (jest ich dziewięć) znajdują się w archiwum rodzinnym wnuka pisarza, Andrzeja Sieroszewskiego. Najwcześniejszy pochodzi z 2I grudnia I925 roku. Samotna czterdziestoparoletnia Maria pisze do ojca po jedenastu latach przerwy, informując go o aktualnej sytuacji starych znajomych, a także własnych problemach: utracie pracy i pogarszającym się stanie zdrowia. Ostatni list, pisany na kartce pocztowej, nosi datę 3I grudnia I830 roku i zawiera podziękowanie za paczkę żywnościową przysłaną przez ojca z Polski, zapewniającą jej na długi czas posiłki. Oby w trakcie dalszych poszukiwań udało się dotrzeć jeszcze do innych listów azjatyckiej córki Sieroszewskiego. Nadzieję tę budzą uwagi obecne w kilku miejscach pierwszej pełnej biografii Wacława Sieroszewskiego, opracowywanej przez wiele lat przez wnuka, a wydanej dopiero w 2015 roku dzięki staraniom wdowy po Andrzeju Sieroszewskim - Krystyny Sieroszewskiej i ich córki Zuzanny Sieroszewskiej-Rolewicz, a przede wszystkim dzięki wysiłkowi redakcyjnemu profesora Andrzeja Z. Makowieckiego ${ }^{\text {II }}$. Jak wynika z sugestii Andrzeja Sieroszewskiego ${ }^{\text {I2 }}$, a także wzmianek samej Marii w zachowanych listach, korespondowała z ojcem przez kilkadziesiąt lat: od czasu jego wyjazdu z Rosji do Polski, czyli od roku I896, do połowy 1933 roku. Okres ten skraca jedenastoletnia przerwa w wymianie listów (I9I4-1925), spowodowana zapewne burzliwymi wydarzeniami historycznymi: wybuchem pierwszej wojny światowej, wojną domową w Rosji w latach I917-1922 i wojną polsko-bolszewicką. Niestety, nie dotarłam do żadnych śladów istnienia listów Wacława Sieroszewskiego do Marii (podejrzewam, że nie ocalały; jest mało prawdopodobne, żeby przechowywane były w jakichś archiwach moskiewskich bibliotek albo znajdowały się w zbiorach prywatnych potomków słynnej rodziny Sierowów, u której Maria mieszkała w ostatnich latach swego życia $\left.{ }^{\mathrm{I}}\right)$.

11 Zob. A. Sieroszewski, Wactawa Sieroszewskiego żywot niespokojny, z rękopisu wyd., oprac. i uzup. A.Z. Makowiecki, Warszawa 2015.

12 Zob. ibidem, s. 356-357.

13 Mowa o rodzinie wybitnego rosyjskiego portrecisty Walentyna Sierowa i jego matce Walentynie Siemionownej Sierowej (1846-1924), utalentowanej kompozytorce, nauczycielce i krytyczce muzyki. Maria Sieroszewska została pochowana w 1964 r. w grobowcu rodzinnym Sierowów (obok Walentyny Sierowej), znajdującym się w Moskwie na cmentarzu Nowodziewiczym. Na płycie nagrobnej pod nazwiskiem Marii Wacławownej Sieroszewskiej figurują daty: 1879-1964. Data urodzin jest 
Brak zachowanych listów Sieroszewskiego do córki znacznie utrudnia przygotowanie objaśnień do listów Marii, a także uniemożliwia rekonstrukcję obustronnej wymiany myśli. Choć nie da się dziś stwierdzić, jaki charakter miał korespondencyjny dialog ojca z córką (na ile był głęboki i bliski), można z pewnością dostrzec w listach Marii „wymowną obecność” adresata. Odtworzenie zachowania, sposobu myślenia i rodzaju emocji Sieroszewskiego w stosunku do pierworodnego dziecka ułatwiają także wypowiedzi pisarza na temat córki rozsiane na stronicach jego pamiętników i wspomnień, autobiograficzne tropy w jego opowiadaniach syberyjskich czy wreszcie obszerna korespondencja z innymi osobami, głównie z Pauliną Sieroszewską, Grigorijem i Aleksandrą Potaninami oraz ze Stanisławem Patkiem.

W archiwum rodzinnym Sieroszewskich (w papierach Władysława Sieroszewskiego, najstarszego syna pisarza) zachowało się natomiast kilka listów Marii pisanych przed pierwszą wojną światową do ciotki, Pauliny Sieroszewskiej ${ }^{\mathrm{I}}-$ zna- $^{-}$ nej publicystki warszawskiej i działaczki społeczno-oświatowej, współredaktorki „Prawdy”. Ich publikacja (na przykład w aneksie zamykającym przygotowywaną edycję) wzbogaciłaby wiedzę na temat relacji Marii z polską rodziną ojca i odsłoniła wielokrotnie wyrażane przez nią pragnienie ściślejszej integracji z jej członkami.

Dokładne określenie rozmiarów korespondencji jakuckiej córki Sieroszewskiego jest dziś praktycznie niemożliwe. Nie wiadomo, jaka jej część ocalała, a jaka uległa zniszczeniu. To jeden z głównych problemów, z którym boryka się edytor, chcąc ogłosić drukiem w miarę możliwości kompletny zespół autografów i opatrzyć go stosownym komentarzem krytycznym. Zespół, który udało mi się do tej pory zgromadzić, liczy trzydzieści trzy listy pochodzące z lat 1925-1933, wysyłane w większości z Moskwy (jedynie dwa są pisane gdzie indziej: jeden w Ałabino, miejscowości oddalonej $40 \mathrm{~km}$ od Moskwy, drugi w nadmorskiej osadzie uzdrowiskowej Koreiz, położonej na Krymie). W zbiorze zachowanych dokumentów znajduje się dwadzieścia sześć listów pisanych na kartach z zeszytu (formatu A5) lub zwykłym papierze listowym (połowa formatu $\mathrm{A}_{4}$ ), siedem kartek pocztowych i siedem kopert. Listy pisane są prostym, zrozumiałym, niejednokrotnie silnie nacechowanym emocjonalnie stylem. Dostarczają wiedzy nie tylko na temat nieznanych dotąd dziejów Marii, wykonywanej przez nią pracy, kłopotów bytowych i nie najlepszej kondycji fizycznej, ale także dużo mówią o osobowości piszącej i jej intymnych sprawach, na przekór stwierdzeniu samej autorki, że „jakoś w liście swojego życia nie da się opisać" (I3 października [1931] $)^{\text {I5 }}$.

z pewnością błędna, ponieważ Sieroszewski dotarł na miejsce zsyłki (do Wierchojańska) dopiero w $1880 \mathrm{r}$.

14 Zob. A. Sieroszewski, Wactawa Sieroszewskiego żywot niespokojny, op. cit., s. 124, 167, 356.

15 Dla wygody czytelników obecnego artykułu cytuję fragmenty listów Marii Sieroszewskiej do ojca w przekładzie na język polski (zespół listów znajdujący się w zbiorach Biblioteki Narodowej przetłu- 
Niemałym dylematem edytorskim jest chronologiczne uporządkowanie całego zbioru. Sieroszewska $\mathrm{z}$ reguły nie opatrywała swoich listów pełnymi datami: niemal konsekwentnie nie zapisywała roku, w nagłówku umieszczała jedynie datę dzienną i miesięczną. Wyjątkiem od tej reguły są tylko trzy listy, mające pełną datację: 3I grudnia [I9]26, 26 lutego[I9]3I i 9 października [I9]32. Rozwiązania problemu ułożenia tekstów we właściwym porządku czasowym nie ułatwiają karty korespondencyjne, na których często figurują mało czytelne stemple pocztowe, ani też zachowane koperty - na kilku $z$ nich znaczki są odcięte albo datowniki na znaczkach są nieczytelne (poza tym koperty w zbiorze rękopisów znajdującym się w Bibliotece Narodowej są przemieszane z listami, do których nie pasują). Na szczęście kartki pocztowe, z których można odczytać datę ze stempli pocztowych, zawierają wskazówki bezpośrednio korespondujące $z$ treścią innych niedatowanych listów, ułatwiające rekonstrukcję dat rocznych i ułożenie dokumentów w odpowiedniej kolejności, tak aby tworzyły spójną i logiczną całość. Chronologiczne uporządkowanie korespondencji Sieroszewskiej w dużej mierze ułatwiają też informacje w jej listach, odsyłające do pewnych faktów z biografii Sieroszewskiego (np. jego wyjazdów służbowych do Anglii i Ameryki czy podróży do Paryża), aktualnych wydarzeń politycznych, momentu publikacji utworów autora Na kresach lasów, kolejnych wizyt Marii w Polsce itd. Nie wszystkie jednak daty roczne listów da się zrekonstruować $\mathrm{z}$ niezachwianą pewnością, że były pisane $\mathrm{w}$ tym, a nie w innym czasie.

Polska edycja rosyjskich listów Marii Sieroszewskiej wymaga szczególnej rozwagi w ustaleniu zasad opracowania tekstu (także w zakresie modernizacji języka). O ile w wypadku polskiego tłumaczenia zachowanej korespondencji sprawa jest prosta $-z$ reguły przyjmuje się, że pisownia i interpunkcja powinny być dostosowane do obowiązujących współcześnie norm poprawnościowych - o tyle dyskusyjne jest, w jakim zakresie polski edytor może ingerować w rosyjski tekst rękopisów. Czy ma prawo unowocześniać oryginalną pisownię $\mathrm{i}$ interpunkcję zgodnie $\mathrm{z}$ powszechnie stosowanymi dziś zasadami edytorskimi? Jeśli tak, to w jakim stopniu? Czy oryginalna pisownia powinna być dostosowana do norm współczesnej ruszczyzny (dotyczy to na przykład kwestii modernizacji form przestarzałych, brzmienia nazwisk, zapisu nazw geograficznych, oboczności leksykalnych czy zwrotów grzecznościowych)? Oprócz rozstrzygnięcia tych wątpliwości należy oczywiście przyjąć jednolity system wyróżniania takich miejsc tekstowych, które dotyczą zapisu: tytułów utworów literackich i wyrażeń obcych (kursywą), tytułów czasopism i cytacji (w cudzysłowie), nazw instytucji (wielkimi literami), podkreśleń wyróżnionych przez piszącą (spacjowaniem) oraz rozwijania konwencjonalnych skrótów (bądź nierozwijania, jeśli ich sens jest oczywisty). 
Samo odczytanie rękopisów listów Sieroszewskiej, które zachowały się w dość dobrym stanie (bez ubytków tekstu), nie nastręcza specjalnych trudności. Pisane są w miarę wyraźnym charakterem, z reguły piórem, rzadziej ołówkiem. Wątpliwości tekstologiczne pojawiają się jednak w miejscach, gdzie autorka używa skrótów niezrozumiałych dla polskiego badacza albo których lekcja jest niejasna. Właściwe ich odczytanie i rozwiązanie potrzebne jest, rzecz jasna, do skonstruowania kompetentnego komentarza filologicznego, niezbędnego do zrozumienia poruszanych w listach spraw. Ze względu na niejednokrotnie zawiłą treść listów zapewne będzie on obszerny (ale oczywiście nie powinien przytłoczyć tekstu głównego) - znajdą się w nim rozszyfrowane skróty imion i nazwisk występujących w autografach, notki biograficzne $z$ niezbędnymi danymi o osobach, o których pisząca informuje adresata, zostaną wyjaśnione aluzje polityczne, przybliżone realia topograficzne i sytuacyjne, skomentowane szczegóły faktograficzne itd. Przyjrzyjmy się wybranym problemom $z$ tego obszaru pracy edytorskiej.

Przede wszystkim niezwykle trudne jest zidentyfikowanie wielu osób, o których pisze Sieroszewska, ponieważ bardzo często oznacza ich nazwiska jedynie inicjałem, używa samych imion bądź inicjałów imion i otczestwa albo skraca nazwiska w sobie tylko wiadomy sposób. Prawdopodobnie stosowała taki zapis ze względów ostrożności - swoje listy wysyłała wszak do byłego członka PPS-Frakcji Rewolucyjnej, bliskiego współpracownika i przyjaciela Józefa Piłsudskiego, ministra propagandy w Tymczasowym Rządzie Ludowym Republiki Polskiej, uczestnika przygotowań do wojny polsko-bolszewickiej, autora utworów będących w ówczesnej Rosji na indeksie ksiąg zakazanych ${ }^{\text {16 }}$, słowem do niebezpiecznego polskiego „wywrotowca”. Możliwe też, że używanie samych inicjałów powodowane było czynnikiem ekonomicznym, odgrywającym rolę wtedy, kiedy musiała w liście powtarzać kilkakrotnie jakieś nazwisko albo odpowiadała bezpośrednio na konkretne zapytanie ojca. Oto przykłady ilustrujące rzeczony problem:

\section{\Nat. Osip. ${ }^{17}$ mieszka w osobnym mieszkaniu i krząta się przy swoim wnuku, wspaniałym chłopcu, bardzo nerwowym i mało podobnym do Mitii (5 lipca [1927]).}

16 Znajdował się na nim m.in. dramat Sieroszewskiego Bolszewwicy. Krytyka bolszewizmu przyczyniła się do wielu napastliwych opinii o polskim pisarzu - reprezentatywnym tego przykładem może być nota z sowieckiej Encyklopedii literatury: „Po wojnie S[ieroszewski] wystąpił jako zawzięty wróg komunizmu i ZSRR.W 1922 napisał sztukę Bolszewicy. Była to w znacznej mierze nieudolna kalumnia na bolszewizm. Mimo wielkiego poparcia ze strony oficjalnych kręgów sztuka poniosła fiasko po kilku przedstawieniach", Litieraturnaja encyktopiedija (t. 1-11, Moskwa 1929-1939, wyd. Chudożestwiennaja Litieratura), t. 10, Moskwa 1937, hasło: Sieroszerwskij, s. 697-698. Cyt za: http://feb-web. ru/feb/litenc/encyclop/lea/lea-6971.htm (stan z 6 listopada 2016 r.), tłum. I. Plucner.

17 Wszystkie wyróżnienia w tekstach cytatów pochodzą od edytora. 
Kiedy L. wyjeżdżali do Warszawy, wołali mnie ze sobą, ale ja powiedziałam ,jedna głowa nie bieda, nie przepadnie”, a jechać w obce środowisko nie chcę ani dla siebie, ani dla otoczenia (I3 kwietnia [1928]).

Czasami bywam w Towarzystwie Katorżan [tj. zesłańców - G.L.] Politycznych, kiedy są tam jakieś wspominki, a najczęściej pogrzeby, ponieważ staruszkowie jeden za drugim odchodzą, latem chowali Min. Was. [...] Fan. Abram. zrobiła się zupełnie maleńka, chudziutka, no ale ona nigdy nie była duża. Jej brat Mich. Abr. mieszka w Odessie i czasami tutaj przyjeżdża (23 grudnia [1929?]).

Mam do ciebie prośbę: napisz proszę kilka ciepłych słów (w moim liście) do Włady. Ona, opowiadałam ci i pisałam, bardzo zmizerniała, schudła, żyje jej się ciężko, ponieważ ma bardzo małą emeryturę. Ja i Lena B. (córka Zofii Andriejewny) pomagamy jej jak możemy (I2 grudnia [1932?]).

Niedawno dostałam list od Feliksy Mikoł., która pisze, że Iw. Iw. przepisał mój dług na nią, a ona teraz potrzebuje pieniędzy, rzecz w tym, że Wanda cały miesiąc chorowała i Lola jakoś długo nie dostaje pensji i dlatego F. M. pyta mnie, jak ty miałeś zamiar płacić, chociaż ja przed odjazdem powiedziałam, ale byłam spokojna, że jeśli ty się spóźnisz, to nie szkodzi, ponieważ Iw. Iw. nie jest w potrzebie i jest mi niemiło, że dług został przeniesiony na F. M. (6 listopada [1930?]).

Przypuszczalnie niektórych występujących w listach osób, określanych jedynie za pomocą imion lub inicjałów nazwisk, nie da się zidentyfikować, zwłaszcza jeśli kontekst zdania czy całego listu niewiele wyjaśnia.

Kolejne wątpliwości edytorskie, towarzyszące polskiemu wydaniu listów Sieroszewskiej, wiążą się z rozszyfrowaniem skrótów nazw jakuckich instytucji lub towarzystw, o których kilkakrotnie jest mowa w korespondencji. Na przykład w liście pisanym w Moskwie I marca I927 roku Maria donosi ojcu:

\ dostałam pracę w Jakucku, gdzie jest dużo Jakutów; między innymi pracuje tutaj Michaił Aleksiejewicz Afanasjew, który kazał cię pozdrowić, bardzo o ciebie dopytywał się Wasilij Wasilewicz Nikiforow, on pracuje w [składzie] ekspedycji do badań obwodu jakuckiego. Tu jest 
teraz dużo studentów i studentek Jakutów; słowem - i tam zaczyna docierać kultura. Często widuję się z Nat. Osip. Kogan-Bernsztejn [...] mają tutaj Two Politkatorżników [tj. Zesłańców Politycznych G.L.], gdzie odbywają się wieczory wspomnień, dokąd teraz też chodzę i spotykam wielu starych znajomych (I marca [1927]).

Otrzymanie przez Marię pracy w Jakucku, która wówczas - jak wiadomo z adresów umieszczanych w nagłówkach listów lub kart pocztowych - mieszkała na stałe w Moskwie, wydaje się nielogiczne. Nazwiska osób, które wymienia w dalszej części zdania, naprowadzają jednak na właściwy trop. Pisząca prawdopodobnie ma na myśli utworzoną w Moskwie sekcję Wydawnictwa Jakuckiego „Jakutizdat”, stanowiącego oddział Centralnego Wydawnictwa Wschodniego (sekcją kierował Serafim Gieorgijewicz Potapow - zasłużony obrońca kultury jakuckiej i tożsamości narodu Sacha). W moskiewskim oddziale tego wydawnictwa oprócz młodych jakuckich studentów pracowało wielu starszych Jakutów, których Sieroszewski poznał na zesłaniu, między innymi Michaił A. Afanasjew, Wasilij W. Nikiforow czy Natalia Osipowna Kogan-Bernsztejn - rosyjska Żydówka, żona powieszonego rewolucjonisty, u której kilkuletnia Masza pobierała lekcje w czasie, kiedy mieszkała z ojcem w Namskim Ułusie. Zasadność tego tropu potwierdza informacja o pracy Nikiforowa w ,jakuckiej ekspedycji”. Ta ostatnia zorganizowana została w I925 roku przez Akademię Nauk ZSRR w ramach pięcioletniego planu badania życia rdzennych mieszkańców kraju nad Leną.

Z dalszych etapów dziejów Marii Sieroszewskiej, które udało mi się odtworzyć, wiadomo również, że praca w „Jakutizdacie”, gdzie była zatrudniona przez kilka miesięcy (przypuszczalnie na etacie księgowe ${ }^{-18}$ ), miała istotne znaczenie dla przyszłych dramatycznych wydarzeń w jej życiu, podobnie zresztą jak utrzymywanie ścisłego kontaktu z Towarzystwem Politkatorżników, o którym pisze w dalszej części listu. Niewykluczone, że w połowie lat trzydziestych albo na początku czterdziestych została, w ramach akcji deportacji „antysowieckiego elementu”, ewakuowana na wschód i internowana w sowieckim łagrze ${ }^{\mathrm{I} 9}$. Stanowiłoby to wy-

18 Domniemanie to nasuwają liczne informacje zawarte w listach do ojca, dotyczące posady księgowej $\mathrm{w}$ różnych firmach. $Z$ reguły pisząca nie podaje nazw tych firm, wyjątek stanowi Kooperatywna Organizacja dla Artystów, gdzie zatrudniła się na początku 1931 r. (list z 26 lutego 1931).

19 Przypuszcza tak jakucka badaczka Maria Gawriłowa, autorka artykułu Córka Sieroszerwskiego - zob. Nomoch. Sieroszerwskaj kyy'a, „KYYM” 2006, http://www.kyym.ru/old/?p=print\&id=1607 (stan z 11 listopada 2011 r.). Informacje Gawriłowej odwołują się do wspomnień rosyjskiego aktora Olega Tabakowa, zawartych w jego książce Moje prawdziwe życie, w której przywołuje on czasy swego pobytu w domu słynnego malarza „pieriedwiżnika” Walentego Sierowa. Gawriłowa pisze: „Wtedy [w latach trzydziestych - G.L.] u gościnnych Sierowych przebywało dużo zwolnionych z GUŁagu przedstawicieli inteligencji. Na przykład potomkowie dekabrysty Pawła Pestela... W książce mowa jest także o tym, że jakiś czas zatrzymywała się w tym domu wnuczka polskiego rewolucjonisty 
tłumaczenie powodu zaprzestania korespondencji z ojcem (wiadomości od Marii, przypomnijmy, urywają się w I933 roku).

W liście pisanym w sierpniu I930 roku, po drugiej wizycie w Polsce i spotkaniu z całą rodziną Sieroszewskiego w Gdyni (jego żoną, trzema synami i teściową), Maria stwierdza, używając kolejnej niejasnej nazwy:
\Na początku, jak przyjechałam, bardzo tęskniłam za wami wszystkimi, a teraz od nowa wciągnęłam się w wir moskiewskiego życia, a do tego wybrali mnie jeszcze na członka naszego miestkomu, a to oznacza: chcesz czy nie chcesz, musisz znowu wziąć pracę społeczną (20 sierp- nia $[1930])$.

Znajomość sytuacji społeczno-politycznej Związku Radzieckiego na progu lat trzydziestych XX wieku nie pozostawia wątpliwości, że mowa jest tu o jakimś lokalnym komitecie związków zawodowych, którego Maria została członkinią.

Podczas pierwszej lektury listów córki Sieroszewskiego mało zrozumiałe są również uwagi dotyczące jej relacji rodzinnych i przyjacielskich. Pisząca wielokrotnie powraca myślą do swoich „bliskich” z Soczi i komentuje ich teraźniejsze losy. W listach występują enigmatyczne określenia typu: „rodzina”, „nasi”, „moi” albo zdrobnienia imion najbliższych jej osób: Kostia, Wołodia, Szura, Waria, Tina, Nadia - sugerujące jakieś nieznane koligacje rodzinne. Oto wybrane przykłady:

\section{\W Soczi teraz rodzina bardzo się przerzedziła: umarł młodszy brat z żoną, umarł starszy Wołodia, mąż Tiny (2I grudnia [1925]).}

Nasi namawiali mnie, żebym spędziła zimę u nich w Soczi, ale postanowiłam wyjechać, bo tam u nich nic się nie wysiedzi, a tylko straci się kontakt z ludźmi i jeszcze trudniej będzie załatwić sobie pracę (8 listopada [1926]).

Nadia obecnie jest nauczycielką w Obwodzie Kubańskim na Północnym Kaukazie, w pobliżu miasta, w którym uczy się jej młodsza córka [...]. Pozostała rodzina rozjechała się w różne strony, chociaż

W[acława] Sieroszewskiego (w rzeczy samej, córka - M.G.), o azjatyckim wyglądzie, Maria Sieroszewska”. Eadem, Nomoch. Sieroszerwskaj kyy'a, op. cit., s. 3. Polski reportażysta Michał Książek utrzymuje z kolei, że Maria nie doświadczyła łagrowej zsyłki i po drugiej wojnie światowej pędziła spokojne życie w moskiewskim domu Walentyny Sierowej - zob. idem, O Marii Sieroszerwskiej, https:// www.sybir.com.pl/pl/historia/1938,O-Marii-Sieroszewskiej.html.pdf (stan z 2 listopada 2016 r.). 
niedaleko jedno od drugiego, także na Kaukazie. Tina mieszka u córki lekarza (I2 stycznia [1932]).

Owe enigmatyczne określenia stają się zrozumiałe w świetle pamiętników i wspomnień Warwary Nikołajewny Żilińskiej, wychowanki Marii Arsieniewny Bykowejpostępowej działaczki oświatowej, która na początku lat osiemdziesiątych XIX wieku przybyła z dwanaściorgiem dzieci do Soczi, gdzie założyła prywatną szkołę, będącą jednocześnie ochronką dla sierot i biednych dzieci zesłańców politycznych. Maria Sieroszewska przyjechała na Kaukaz do sierocińca Bykowej w $1897 \mathrm{roku}^{20}$, kiedy miała czternaście lat (wcześniej, tj. po wyjeździe Sieroszewskiego do Petersburga, a następnie jego powrocie do Polski, opiekowali się nią przyjaciele ojca: Stanisław i Felicja Landowie). Rychło zaprzyjaźniła się tu z adoptowaną przez Bykową czwórką rodzeństwa, dziećmi zmarłych zesłańców Nikołaja Żilińskiego i Olgi Pelc, mianowicie z Konstantinem, Władimirem, Aleksandrem i Warwarą Żilińskimi. Znajomość tych faktów pozwala zidentyfikować osoby, o których pisze Sieroszewska, używając zdrobnień imion: Kostia, Wołodia, Szura, Waria. Oprócz rodzeństwa Żilińskich do owej „przyszywanej” kaukaskiej familii Marii należały jej dwie serdeczne przyjaciółki: Tina (Tina Biełojarcewa, późniejsza żona Wołodii Żilińskiego) i Nadia (Nadieżda Sierowa, właśc. Nadieżda Niemczynowa, późniejsza Żilińska). Ta ostatnia przyjechała do Wołkowki ${ }^{21}$ ze swoją matką Walentyną Siemionowną Sierową ${ }^{22}$. Maria, opuszczona przez ojca, tęskniła - co oczywiste - do posiadania własnej rodziny, toteż traktowała Żilińskich jak braci, a Nadię, Tinę i Warię jak siostry²3. Najbardziej - o czym świadczą jej liczne uwagi w listach do ojca z lat trzydziestych - zżyła się z Nadią, z którą w późniejszym czasie utrzymywała bliski kontakt. W drugiej połowie lat dwudziestych pomagała jej w Soczi w kilkumiesięcznej opiece nad ciężko chorym synem, a na początku lat trzydziestych spotykała się z nią wielokrotnie w Moskwie, gdzie mieszkała na stałe.

Z zawiłymi koligacjami rodzinnymi Marii wiążą się ponadto budzące wątpliwości wzmianki w zachowanej epistolografii o innych jeszcze krewnych. Na przykład w liście z I2 stycznia [1932] roku wspomina:

20 Zob. E. Diewina, Swoja sistiema obuczenia. Marija Arsieniewna Bykowa szczytajetsa pierwoj uczytielnicoj naszego goroda, „Nowostki Soczi”2007, nr 23 (585), s. 3.

21 Po zamieszkaniu w Soczi Bykowa kupiła w pobliskiej okolicy ziemię, na której zorganizowała - na wzór osad tołstojowców - kolonię Wołkowka. Realizowano w niej zasadę samodoskonalenia przez pracę (zajmowano się głównie uprawą roli) i bezinteresownego czynienia dobra bliźnim.

22 Nadia była córką Walentyny Siemionowny Sierowej z drugiego małżeństwa, zawartego - po śmierci Aleksandra Sierowa - z lekarzem Wasilijem Niemczynowem.

23 Warwara Żilińska podkreśla w swych wspomnieniach, że Maria nigdy nie straciła kontaktu z rodziną Żilińskich. Zob. A. Jewstafiew, Docz Sieroszerwskowo, http://www.pois-yakutia.ru/show. php?id=13482 (stan z 14 listopada 2011 r.). 
\Oczywiście zawsze mi miło dostać od was paczkę i to trochę przypomina mi dzieciństwo i Irkuck, kiedy ty i babcia przysyłaliście mi coś i ja z niecierpliwością otwierałam paczkę. Ale zawsze mam wyrzuty sumienia za fatygowanie was i że nie mam ze swej strony czym się odpłacić poza wdzięcznością za waszą troskę (I2 stycznia [1932]).

Ową babcią, która przysyłała Marii paczki do Irkuckaª ${ }^{24}$ okazuje się teściowa Sieroszewskiego, Jadwiga Mianowska - ukochana babcia trzech synów Stefanii i Wacława Sieroszewskich (Władysława, Stanisława i Kazimierza), przyrodnich braci Marii, mieszkająca z rodziną córki do swej śmierci (tj. do 1928 roku), „wielce pomocna w opiece nad wnukami, bardzo ceniona i szanowana przez zięcia”25.

W innym miejscu Maria informuje ojca: „Twój list od matki dostałam” (2o sierpnia [1930]); dziękuje: „Jeszcze raz dziękuję tobie i mamie za troskę o mnie” (2I grudnia [1931]); pyta: „Jak zdrowie mamy?” (9 listopada [1932]) albo prosi:

1) Nie wiem, czy dostajesz wszystkie moje listy? Pisałam ci ostatni list, licząc na to, że otrzymasz go przed odjazdem, ale w waszej kartce ani słowa o tym nie wspominacie. W ogóle proszę, powiadamiaj o tym, albo jeśli będzie pisać mama. Bardzo jej jestem wdzięczna, że pisze do mnie, tylko że nie mogę jej odpowiadać.

Czy Staś przeniósł się do Warszawy? Mama obiecała napisać mi szczególowy list o wszystkich. Pewnie ona teraz też bardzo zajęta u siebie w szkołach (29 września [1930]).

Oczywiście nie może tu być mowy o biologicznej matce Marii (Arina Czełba-Kysa zmarła, przypomnijmy, na przełomie 1886 i 1887 roku, kiedy jej córeczka miała pięć lat), lecz o macosze - drugiej żonie Wacława Sieroszewskiego, Stefanii Sieroszewskiej z Mianowskich, którą Maria poznała bliżej w czasie wizyty w Paryżu, tuż przed pierwszą wojną światową i od tego czasu nazywała ją w listach pisanych do ojca „matką”.

Tego rodzaju ciekawostek i zagadek listy Marii Sieroszewskiej kryją wiele, inspirując edytora do poszukiwań i dostarczając mu wiele satysfakcji w momencie, kiedy

24 Po siedmiu latach wspólnego mieszkania z ojcem, najpierw w Bajagantajskim Ułusie (1885-1887), a potem w Namskim Ułusie (1887-1892), dziesięcioletnia Masza opuściła Jakucję i przeniosła się z ojcem do Irkucka, gdzie spędziła u jego boku kolejne radosne lata swojego dzieciństwa (1892-1894). Po wyjeździe Sieroszewskiego do Petersburga (1894), a następnie jego powrocie do Polski (1896) pozostała w Irkucku pod opieką Felicji i Stanisława Landych.

25 A. Sieroszewski, Wactaw Sieroszerwski w kręgu rodziny i przyjaciót, w: Wactaw Sieroszerwski. Zestaniecetnograf-literat-polityk, red. A. Kuczyński i M. Marczyk, Wrocław 2011, s. 22. 
odkrywa intrygujące fakty czy nieznane tropy biograficzne, wiodące do poznania dramatycznej historii życia tej wrażliwej i samotnej kobiety (nie założyła bowiem własnej rodziny), jej nietuzinkowej osobowości, charakteru i usposobienia. Listy pisane przez nią do ojca odsłaniają z jednej strony oblicze osoby prostodusznej, pełnej dobroci i życzliwości wobec innych, która przyjmuje swój los z pokorą, z drugiej - silnej, mądrej i dumnej, nieujawniającej słabości nawet wtedy, kiedy pozbawiona pracy głoduje i nie ma za co ogrzać zimnego mieszkania. Przede wszystkim jednak z zachowanej korespondencji wyłania się psychologiczny portret dojrzałej córki, bezgranicznie kochającej swojego ojca, potrafiącej mu wybaczyć sprawiany sobie nierzadko zawód i zrozumieć jego życiowe wybory.

Postać Marii Sieroszewskiej - mieszkającej w Moskwie skromnej urzędniczki, która - mimo opuszczenia w dzieciństwie przez rodziców ${ }^{26}$, niełatwych przeżyć w sierocińcu, samotności i braku silnie ugruntowanej tożsamości kulturowej (będąc pół-Jakutką, pół-Polką, w istocie czuła się Rosjanką) - z pewnością zainteresować może szeroki krąg odbiorców. Dlatego sądzę, że warto i należy wydać jej listy pisane do ojca w latach 1925-I935. Oczywiście, publikując je zarówno w języku rosyjskim, jak i w polskim przekładzie oraz opatrując wyczerpującym komentarzem krytycznym. Umożliwiają one przecież nie tylko rekonstrukcję złożonej i pełnej wciąż niewyjaśnionych miejsc biografii jedynej córki autora Dwunastu lat w kraju Jakutów, ale także uzupełnienie stanu wiedzy na temat dziejów jej ojca. Publikacja ta może być również pomocna dla badaczy zajmujących się literaturą dokumentu osobistego oraz dla czytelników interesujących się rodzinnymi koligacjami polskich zesłańców syberyjskich z rdzennymi mieszkańcami egzotycznego dla Europejczyka kraju nad Leną.

\section{Bibliografia:}

Diewina E., Swoja sistiema obuczenia. Marija Arsieniewna Bykowa szczytajetsa pierwoj uczytielnicoj naszego goroda, „Nowostki Soczi” 2007, nr 23 (585);

Gawriłowa M., Nomoch. Sieroszerwskaj kyy'a [Córka Sieroszerwskiego], „KYYM”2006, http://www.kyym.ru/ old/?p=print\&id=1607;

Jewstafiew A., Docz Sieroszerwskowo, http://www.pois-yakutia.ru/show.php?id=13482;

Książek M., O Marii Sieroszerwskiej, https://www.sybir.com.pl/pl/historia/1938,O-Marii-Sieroszewskiej. html.pdf;

Legutko G., Meandry ojcowskiej mitości. Wokót listórw jakuckiej córki Wactawa Sieroszerwskiego, „Wrocławskie Studia Wschodnie" 2012, nr 16;

Mitologizacja przesztości i problem z tożsamościq. Uwagi na marginesie listów Marii Sieroszerwskiej, w: Tożsamość - Czas - Pamięć, red. B. Morzyńska-Wrzosek, I. Szczukowski, Bydgoszcz 2017;

26 Matka oddała ją jako roczne dziecko na wychowanie swym krewnym, osierociła ją w wieku pięciu lat, ojciec zaś zostawił w carskiej Rosji pod opieką przyjaciół, kiedy miała lat czternaście. 
Legutko G., Sadowska I., Bojownicy polskiej sprawy. Wactaw Sieroszerwski i Gustaw Danitowski wobec myśli i czynu Józefa Pitsudskiego (Wybór materiatów z lat 1898-1943), Kielce 2007;

Listy Wactawa Sieroszerwskiego do Stefana Żeromskiego i Oktawii Żeromskiej z lat 1897-1902, w: Literatura

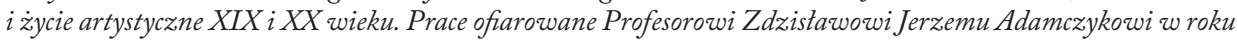
Jubileuszu, red. B. Utkowska i K. Jaworski, Kielce 2006;

Rowniakowa L., Wactaw Sieroszerwskij i jego russkije korespondenty, w: eadem, Stawianskije litieraturnyje swiazi, Leningrad 1968;

Sadowska I., Wśód obcych i wśród swoich. Wactawa Sieroszerwskiego portret wielokrotny, red. G. Legutko, Kielce 2007;

Sieroszewski A., Stowo i czyn. Życie i twórczośc Wactawa Sieroszerwskiego, w: Z kraju nad Lenq. Związki polsko-jakuckie dawniej i dzis, red. A. Kuczyński, Wrocław 2001;

Wactaw Sieroszerwski w kręu rodziny i przyjaciót, w: Wactaw Sieroszerwski. Zestaniec-etnograf-literat-polityk, red. A. Kuczyński i M. Marczyk, Wrocław 2011;

Wactawa Sieroszerwskiego żywot niespokojny, z rękopisu wyd., oprac. i uzup. A.Z. Makowiecki, Warszawa 2015;

Sieroszewski W., Listy z Syberii, oprac. B. Kocówna, w: Miscellanea z pogranicza XIX i XX wieku, red. S. Pigoń, „Archiwum Literackie”, t. 8, Wrocław-Warszawa-Kraków 1964 i nadb.;

Syberyjscy mistrzowie Sieroszewskiego. Listy do G.N. i A.W. Potaninów, oprac. B. Koc, „Blok-Notes Muzeum Literatury im. Adama Mickiewicza" 1999, nr 12/13;

Takasajewa K.R., Pis'ma M.W. Sieroszewskoj (1882-1964) otcu Wactawu Sieroszewskomu, „Jakutskij Archiw” 2013, nr 1 (44).

SŁOWA KLUCZE: korespondencja Marii Sieroszewskiej, Wacław Sieroszewski, związki polsko-jakuckie

\section{Grażyna LEgutKo}

Editorial problems and doubts connected with the Polish edition of Maria Sieroszewska's letters written in Russian to her father (I925-1933)

The article concerns the edition of letters written in Russian by Maria Sieroszewska, a Yakutian living in Moscow, to her father Wacław Sieroszewski, a famous writer of a Young Poland movement, who lived in exile in Yakutia for twenty years, married a Yakutian and formally acknowledged a child born as a result of this relationship as his own. The collection of 33 letters written by Maria Sieroszewska in the $20^{\mathrm{s}}$ and $30^{\mathrm{s}}$ of the $20^{\text {th }}$ century will be published in its original language and in the Polish translation. The preparation of the issue is accompanied by many problems and doubts: beginning with the Polish translation of the Russian manuscripts and the issue of modernizing the spelling and punctuation of the original, via the difficulties 
276

with establishing the chronology of the letters (they usually do not have dates) and essential linguistic commentary of their content (e.g. decoding of names and surnames' abbreviations, explaining the topography and factual details), finishing with the reconstruction of the full biography of Maria Sieroszewska, which still is very unclear, and also with broadened knowledge about her father's life.

Key words: Maria Sieroszewska's correspondence, Wacław Sieroszewski, Polish-Yakutian relationships 